\title{
Students Satisfaction towards the University: Does Service Quality Matters?
}

\author{
Chuah Chin Wei \\ School of Business Management, College of Business, Universiti Utara Malaysia, \\ 06010 UUM Sintok, Kedah, Malaysia \\ Tel: 60-4-928-3774Ｅ-mail: francischuah@uum.edu.my \\ Subramaniam Sri Ramalu (Corresponding author) \\ School of Business Management, College of Business, Universiti Utara Malaysia, \\ 06010 UUM Sintok, Kedah, Malaysia \\ Tel: 60-4-928-3781Ｅ-mail: subra@uum.edu.my
}

Received: November 7, 2011 Accepted: December 3, 2011 Published: December 10, 2011 doi:10.5296/ije.v3i2.1065 URL: http://dx.doi.org/10.5296/ije.v3i2.1065

\begin{abstract}
This study examines the relationship between service quality (SQ) and the level of student's satisfaction (SS) using a field study of 100 undergraduate students in one of the university in Malaysia. The findings of this study reveals that SQ is a vital factor that determines the level of SS. Specifically, the result of this study reveals that the better the SQ provided by the university, the higher the level of SS. Responsiveness, assurance, and empathy are the three dimensions of SQ that is significantly related to the level of SS. The findings of this study have made significant contribution to the body of knowledge in student's satisfaction management in higher education institutions. The findings of this study also made practical implication to management of higher education especially in the area where SQ improvement is needed
\end{abstract}

Keywords: Service quality, Customer satisfaction, University

\section{Introduction}

The importance of both service quality (SQ) and customer satisfaction (CS) has received considerable attention in the recent years (Ibanez, Hartman \& Calvo, 2006; Sureshchandar, 
Rajendran, \& Anantharaman, 2002). Organizations leveraging on SQ capabilities have reported competitive advantage such as increase of retention and loyalty (Ruyter, 1997; Shemwell, Yavas \& Bilgin, 1998; Alexandris, Dimitriadis \& Markate, 2002). In an era of globalization and stiff competition, organizations began to shift the paradigm of service quality to customer's perspective (Parasuraman, Zeithaml \& Berry, 1985). By relying on this paradigm; a customer will judge the quality of service if the service he/she received meets his/her expectations (Gronroos, 1984; Parasuraman et al., 1985, 1988).

Numerous studies had been conducted on service quality (SQ) and customer satisfaction (CS) in the marketing/management field for the past 30 years. Despite this development, limited research has been done in education field particularly in Malaysian context. Few noticeable research on service quality in higher education institutions are those of Hishamuddin, Azleen, Rahida and Mohd Zulkeflee (2008), Nek Kamal, Azman, Zubrina and Salomawati (2009), and Muhammad, Rizwan and Ali (2010). Findings from these studies reported that student's satisfaction towards services provided by the university is crucial determinants of institutional survival and excellence. Nek Kamal et al. (2009) for instance emphasizes that the proper use of dimensions in SQ in providing services will increases the student's perception towards the value of services. For example, the tangibility of facilities within the institution is important in creating the image of excellence of the institutions (Muhammaed, Rizwan \& Ali, 2010). This finding echoed in Landrum (2007) whereby SQ found to be an important element that determines the success of an institution.

Therefore, this study intends to look into the service quality (SQ) provided by the public institution of higher education and the level of student satisfaction (SS) in one of the public university in Malaysia. The present study contributes to research on SS and SQ in both knowledge and practical aspect. By testing the existing model of SQ and SS in the local context, the results of this study will further reassure whether the existing relationships established from past researches can be generalize to higher education institution in Malaysia. While majority of the studies have been conducted in western context, little is known about the effects of SQ on SS in eastern culture like Malaysia. Practically; the research contributes to educators and management of higher institution by highlighting the important factors affecting student's satisfaction. This will enable the management of the university to identify the strength and weaknesses in the present service quality offered to students and make necessary improvement to increase student's satisfaction.

\section{Theoretical Development and Hypotheses}

\subsection{Student Satisfaction}

For the past 30 years ending 2011, customer satisfaction (CS) has been an intensively discussed subject in the area of consumer and marketing research. According to Wilkie (1990) and Perkins (1991), there have been more than 1200 articles published in the area of customer satisfaction research. The number of the articles published should be doubled or tripled by now since the topic itself has manage to gain more and more attention from scholars around the world. In this study, the CS referred to student satisfaction (SS) since students are considered as a customer for the higher learning institutions. For this study, customer refers to 
university students, hence students satisfaction towards services offered by public institution has become the focus of this research.

McDougall and Levesque (2000) defined customer satisfaction (CS) as "a cognitive or affective reaction that emerges in response to a single or prolonged set of service encounters." Customer satisfaction can be a multi-dimensional construct (Hu, Jay \& Thanika, 2009; Bitner and Hubbert, 1994; Price, Arnould \& Tierney, 1995; Sureshchandar et.al., 2002) or a one-dimensional construct (Cronin \& Taylor, 1992). Regardless of how customer satisfaction is measured, it is proven that a satisfied customers will exhibit loyalty and provide positive word-of-mouth as per reported by Kim, Lee and Yoo (2006). Machleit and Mantel (2001) describe customer satisfaction as the heart of all marketing activities and there is no doubt that customer satisfaction has been identified as one of the most important determinant to customer loyalty.

In the context of higher learning institution, the student satisfactions (SS) play an important role in determining the originality and accuracy of the education system. This is because the higher the level of satisfaction experienced by the student, the better the student's ability to groom their skill development, course knowledge and mentality (Muhammad et al., 2010). Zeithaml (1988) mentioned that the student satisfaction is an evidence to measure how well effective an institution administrates itself as well as its educational system. Rodie and Klein (2000), posited that if an institution possesses essential educational facilities with affective teaching and training staff, the student will most likely be more motivated, loyal and good performers in their academic.

\subsection{Service Quality}

According to Zeithaml and Bitner (2003), service quality (SQ) is defined as a focused evaluation that reflects the customer's perception of specific dimensions of services provided. The particular perception towards the dimensions of services is influenced by several factors which includes the quality of the services received, the quality of the product, the price factor as well as both situational and personal factor (Zeithaml \& Bitner, 2003).

The most notable contribution towards the measurement of quality of a given service is by Parasuraman, Zeithaml and Berry (1985). Their Service Quality (SERVQUAL) model which is a multi-item scale developed to assess customer perceptions of service quality in service and retail businesses (Parasuraman et.al., 1988). At least 293 important articles have been written from 1976 to 1995 on service quality and if consider article in which service quality forms a part of the published articles, the number would be more than 4000 articles (Philip \& Hazlett, 1997). These numbers clearly shows the importance of service quality and the researcher's attentions to the topic.

The initial SERVQUAL model by Parasuraman (1985) consists of ten dimensions namely:

i. Reliability: How well does the service being delivered as promised

ii. Responsiveness: How fast does the response be given to customers

iii. Competence: How well does the service provider possesses the knowledge and skill 
needed to serve the customers

iv. Access: How convenient does customers are able to access the service provider

v. Courtesy: How approachable does the staff of the service provider

vi. Communication: How well does the service provider kept the customers informed

vii. Credibility: How well does the service provider can be trusted

viii. Security: How well does the service provider protect the privacy of customers

ix. Understanding of customer: How well does the service provider make its effort to understand the needs and wants of the customer

x. Tangible: How well does the service provider equipped with tangible facilities to serve the customer.

Parasuraman and Berry (1991) later condensed the ten dimensions of service quality (SQ) into five dimensions which consist of 22 attributes. The newly condensed five dimensions of SQ are as follows:

i. Tangibles: The physical facilities, equipment that is needed to provide services

ii. Reliability: The ability to deliver the desired service dependably, accurately and consistently.

iii. Responsiveness: The ability to response to customers request on time

iv. Assurance: The ability to convey trust and confidence to customers toward the services provided

v. Empathy: The ability to show personal caring and attention to customers.

The SERVQUAL instrument has demonstrated excellent validity and reliability in previous research (Babakus \& Boller, 1992; Bolton \& Drew, 1991; Cronin \& Taylor, 1992). It is applicable to various industries, for example, the adaptation of the instruments in the professional service industries (Freeman \& Dart, 1993), health care (Lam, 1997), and tourism (Tribe \& Snaith, 1998).

The first few adapters of SERVQUAL measurement are Kettinger and Lee (1994) and Pitt et al. (1995). They adapted the SERVQUAL measurement instrument into the information system (IS) context. Since then, the adaptation of SERVQUAL began to expand in an extensive array of industries. Harrison-Walker (2000) adapted the instrument and made a survey in a saloon industry. The finding of the study indicates that consumers do not clearly differentiate the interaction aspects of reliability, responsiveness, assurance and empathy. This means that consumer in the saloon industry gives a general, overall attitude towards their interaction quality with the hairdressers. Azman, Muhammad Madi and Balakrishnan (2009) adapted the instrument to measure the effects of service quality towards the satisfaction of academic staff in public institution of higher learning. The finding of the study indicate that the dimension of service quality indeed impact the satisfaction of academic staff. 
Ravichandran, Mani, Kumar and Prabhakaran (2010) in their study on influence of service quality on customer satisfaction in the context of banking industry found that only the dimension of responsiveness is significantly related to customer satisfaction.

\subsection{Service Quality and Student's Satisfaction}

It is noticeable that service quality (SQ) has always been a critical prerequisite for ensuring the satisfaction of customer in order to maintain a long term relationship with the customer and to sustain customer loyalty (Spreng \& Mckoy, 1996). According to Lassar, Manolis and Winsor (2000), it is crucial to understand the antecedents and determinants of customer satisfaction (CS) since it has an extraordinary high monetary value for service organization in a very competitive business environment. This statement is further support by Bitner (1990) as he researched 145 tourists and found that SQ has been an important determinant of CS.

Prior study by Bigne, Moliner and Sanchez (2003) revealed that the overall dimension of service quality (SQ) have a significant relationship with satisfaction at ( $r=0.66)$. A study in the higher education setting by Ham and Hayduk (2003) shows that there is a significant positive correlation between SQ and student satisfaction (SS) with the dimension of reliability ( $r=0.547$ ) has the strongest relationship with SS followed by empathy and responsiveness (both $r$ 's $=0.5431)$, assurance $(r=0.492)$ and tangibility $(r=0.423)$.

A recent research by Hishamuddin et al., (2008) in the Malaysian higher learning institution indicates that there are significant and positive relationships between the dimensions of service quality (SQ) and student satisfaction (SS). The dimension of empathy is strongly correlated with SS $(\mathrm{r}=0.640)$ followed by assurance $(r=0.582)$, tangibility $(r=0.568)$, responsiveness $(r=0.556)$ and reliability $(r=0.555)$. The alpha coefficients for the dimensions of SQ are above 0.75 indicates that the 22 attributes for SQ can be used to measure the SQ in the education industry (Nunally, 1978). This supports the argumentation that with minor modification the instrument can be adapted to any service organizations (Parasuraman et.al., 1985, 1998; Brown, Churchill \& Peter, 1993; Joseph \& Joseph, 1997; Pariseau \& McDaniel, 1997; Oldfield \& Baron, 2000; Wisniewski, 2001).

Drawing from the above literature discussion, we propose the following hypotheses:

$\mathrm{H}_{1}$ : Service quality is related to student satisfaction.

Specifically:

$\mathrm{H}_{1} \mathrm{a}$ : There is a relationship between the tangible dimension of service quality and student satisfaction.

$\mathrm{H}_{1} \mathrm{~b}$ : There is a relationship between the reliability dimension of service quality and student satisfaction.

$\mathrm{H}_{1} \mathrm{c}$ : There is a relationship between the responsiveness dimension of service quality and student satisfaction.

$\mathrm{H}_{1} \mathrm{~d}$ : There is a relationship between the empathy dimension of service quality and student satisfaction. 
$\mathrm{H}_{1} \mathrm{e}$ : There is a relationship between the assurance dimension of service quality and student satisfaction.

From the above literature discussion and proposed hypothesis, we developed a conceptual framework for this study as shown in Figure 1.

Independent variable

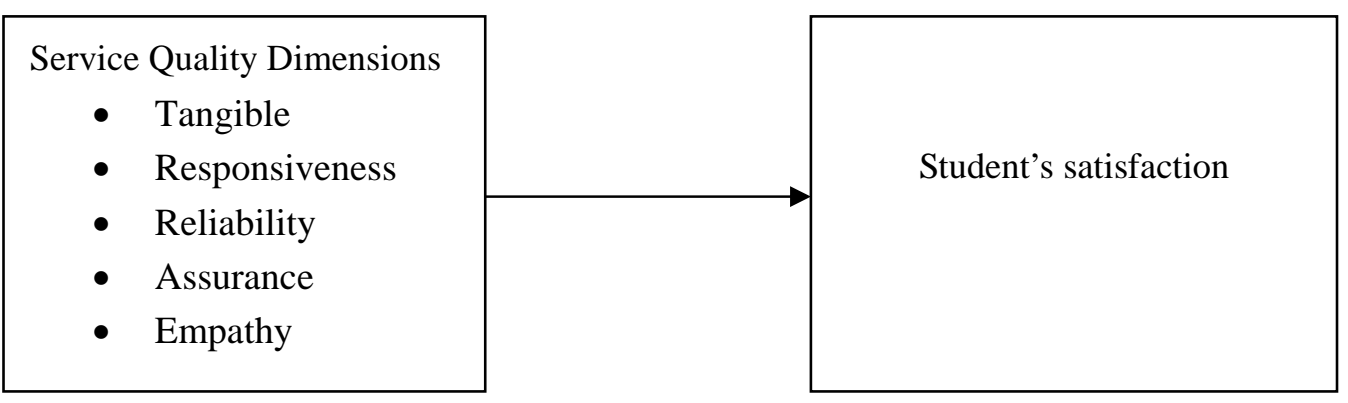

Figure 1. Conceptual framework of effects of Service Quality towards the student's satisfaction

\section{Methodology}

Data were obtained from students using a structured questionnaire through a field survey. Respondents for the study were students who are currently studying in one of the public university in northern region of Malaysia. The students are required to rate their level of satisfaction towards the service quality provided in the area of: i) the academic department, ii) the university sport center, iii) the university residential hall, iv) the transportation services provided by the university and finally, v) the internet services provided by the university. A total of 250 questionnaires were distributed to the respondents using the convenient sampling method. Of these, 100 usable questionnaires received, representing $40 \%$ of response rate.

The sample included 27 (27\%) male and 73 (73\%) female. We studied 4 (4\%) participants aged less than 20 years old, 95 (95\%) participants aged between 21 to 25 years old and 1 (1\%) participant aged between 26 to 30 years old. Out of the 100 participants, 23 (23\%) are Malay students, 68 (68\%) are Chinese students, 7 (7\%) are Indian students and 2 (2\%) are student from other races. Majority of the participants in this study are year 3 student (74 students) followed by year 1 student (12 students). The demographic statistic of this study is exhibited in Table 1. 


\section{Mll Macrothink}

International Journal of Education

ISSN 1948-5476

2011, Vol. 3, No. 2: E15

Table 1. Demographic Statistics $(\mathrm{N}=100)$

\begin{tabular}{|c|c|c|c|c|}
\hline Variables & Frequency & Percentage (\%) & $\mathbf{M}$ & SD \\
\hline \multicolumn{5}{|l|}{ Age } \\
\hline$<20$ & 4 & 4.0 & 1.97 & .223 \\
\hline $20-25$ & 95 & 95.0 & & \\
\hline $26-30$ & 1 & 1.0 & & \\
\hline \multicolumn{5}{|l|}{ Gender } \\
\hline Male & 27 & 27.0 & 1.73 & .446 \\
\hline Female & 73 & 73.0 & & \\
\hline \multicolumn{5}{|l|}{ Race } \\
\hline Malay & 23 & 23.0 & 1.88 & .608 \\
\hline Chinese & 68 & 68.0 & & \\
\hline Indian & 7 & 7.0 & & \\
\hline Others & 2 & 2.0 & & \\
\hline \multicolumn{5}{|l|}{ College } \\
\hline Business & 87 & 87.0 & 1.23 & .617 \\
\hline Law & 3 & 3.0 & & \\
\hline Art \& Science & 9 & 9.0 & & \\
\hline \multicolumn{5}{|l|}{ Year of Study } \\
\hline Year 1 & 12 & 12.0 & 2.76 & .754 \\
\hline Year 2 & 7 & 7.0 & & \\
\hline Year 3 & 74 & 74.0 & & \\
\hline Year 4 \& Above & 7 & 7.0 & & \\
\hline
\end{tabular}

\subsection{Measures}

\subsubsection{Service Quality}

Service Quality was measured with the 22-item SERVQUAL instrument developed by Parasuraman et.al. (1991). The 22-item instrument made up of five dimensions with the dimension of tangible consists of 4 questions, reliability (5 questions), responsiveness (4 questions), assurance (4 questions), and empathy (5 questions). Numerous studies also supported similar measurement practice (Nguyen \& LeBlanc, 1998; Ruyter,Wetzels, \& Bloemer, 1998; Sivadas \& Baker-Prewitt, 2000). Respondent were asked to use a 5-point Likert-type scale to indicate the extent to which they agree with the overall level of service quality provided by the university. Response choice alternatives ranged from 1 (strongly disagree) to 7 (strongly agree). The reliability value (Cronbach's alpha) and number of items in each dimension are presented in Table 1. The reliabilities ranged from 0.65 to 0.94 suggesting that the scale could be used with confidence.

\subsubsection{Student Satisfaction}

Student satisfaction was measured with the 10-item instrument adapted from various sources of literature. (Monroe, 1990; Teboul, 1991; Voss, 1998; Klara, 2001; Belman, 1996; Dulen, 1998; Berry, 1980; Lovelock, 1981; Grove \& Fisk, 1983; Grove, Fisk \& Bitner, 1992). The 
5-point Likert-type scale ranges from 1 (strongly disagree) to 5 (strongly agree) is used to measure the level of agreement toward given statements that represent student satisfaction. The reliability value (Cronbach's alpha) for the 10-item instrument stands at 0.876 as presented in Table 1 suggesting that this self developed instrument could be used with confidence to represent customer satisfaction.

\section{Results}

\subsection{Descriptive Statistics, Reliability Coefficients and Correlations}

The descriptive statistics for all variables are presented in Table 2, along with the correlation matrix. All five dimensions of service quality (SQ) are correlated positively with student satisfaction (SS) (tangible $r=.41$, reliability $r=.69$, responsiveness $r=.76$, empathy $r=.77$, assurance $r=.76$, all $p \mathrm{~s}=<.05$ ). The strongest correlation was found between SS and empathy dimension ( $r=.77, p=<.05)$ followed by assurance $(r=.76, p=<.05)$, responsiveness $(r=.76, p=<.05)$ and reliability $(r=.69, p=<.05)$. The weakest correlation is with the dimension of tangible $(r=.41, p=<.05)$. The result from correlation test preliminary support the proposed hypothesis that all dimensions of SQ have a relationship with SS.

Table 2. Construct intercorrelations and scale reliability values

\begin{tabular}{|c|c|c|c|c|c|c|c|c|c|}
\hline Variable & $\begin{array}{l}\text { No of } \\
\text { Item }\end{array}$ & Mean & SD & $\begin{array}{c}\text { Customer } \\
\text { Satisfaction }\end{array}$ & Tangible & Reliability & Responsiveness & Assurance & Empathy \\
\hline $\begin{array}{c}\text { Customer } \\
\text { Satisfaction }\end{array}$ & 10 & 2.71 & .68 & $(.876)$ & & & & & \\
\hline Tangible & 4 & 3.02 & .69 & $.414^{*}$ & $(.754)$ & & & & \\
\hline Reliability & 5 & 2.46 & .77 & $.689 *$ & $.468^{*}$ & $(.896)$ & & & \\
\hline Responsiveness & 4 & 2.40 & .83 & $.759 *$ & $.477^{*}$ & $.762 *$ & $(.874)$ & & \\
\hline Assurance & 4 & 2.53 & .86 & $.755^{*}$ & $.455^{*}$ & $.770 *$ & $.808^{*}$ & (.909) & \\
\hline Empathy & 5 & 2.39 & .81 & $.770 *$ & $.364 *$ & $.680 *$ & $.748 *$ & .760 & $(.891)$ \\
\hline
\end{tabular}

\subsection{Hypothesis Testing}

The first hypothesis was: Service quality (SQ) is related to student satisfaction (SS). A simple linear regression analysis was conducted to test the hypothesis. The result of the regression analysis for this hypothesis was statistically significant, $R^{2}=.830$, Adjusted $R^{2}=.829, F$ (1, $99)=479.73, p<.05 .83 \%$ of the variance in SS is accounted by SQ. Service quality is statistically significant $(\beta=.911, p=0.001)$. The sub-hypothesis 1 , predicted that tangible $\left(\mathrm{H}_{1} \mathrm{a}\right)$, reliability $\left(\mathrm{H}_{1} \mathrm{~b}\right)$, responsiveness $\left(\mathrm{H}_{1} \mathrm{c}\right)$, empathy $\left(\mathrm{H}_{1} \mathrm{~d}\right)$ and assurance $\left(\mathrm{H}_{1} \mathrm{e}\right)$ will be related to SS.

A multiple regression analysis was conducted to test the above mentioned sub-hypothesis. The result of the multiple regression analysis is shown in Table 3. The regression model is statistically significant. $R^{2}=.695, F(5,99)=42.821, p<.05$. The result of the multiple 
regression analysis is shown in Table 3.

Table 3. Results of multiple regression analysis with dimensions of service quality as predictor of student satisfaction $(\mathrm{N}=100)$

\begin{tabular}{cccc}
\hline Variable & $\boldsymbol{\beta}$ & $\boldsymbol{t}$ & $\boldsymbol{p}$ \\
\hline Tangible & .032 & .477 & .634 \\
Reliability & .075 & .766 & .445 \\
Responsiveness & .225 & 2.035 & .045 \\
Assurance & .242 & 2.151 & .034 \\
Empathy & .356 & 3.772 & .000 \\
\hline
\end{tabular}

$R^{2}=.695$, Adjusted $R^{2}=.679, F(5,99)=42.481, p=0.001$

Responsiveness was positively related to student satisfaction (SS) ( $\beta=.225, p<.05$ ) indicating that the higher the level of responsiveness, the higher the level of student's satisfaction. Assurance $(\beta=.242, p<.05)$ was positively related to SS, indicating that the higher the level of assurance provided by the university, the higher the level of student's satisfaction. Finally, empathy $(\beta=.356, p<.05)$ was positively related to SS, indicating that the higher the level of empathy provided by the university, the higher the level of student's satisfaction. The above findings support the hypothesis $\mathrm{H}_{1} \mathrm{c}, \mathrm{H}_{1} \mathrm{~d}, \mathrm{H}_{1} \mathrm{e} . \mathrm{R}^{2}$ value of 695 indicates that $69.5 \%$ of the variance in SS is explained by the five dimensions of SQ.

\section{Discussion and Conclusion}

This study explored how service quality (SQ) is related to the student satisfaction (SS) of higher learning institution in Malaysia. The result indicated that overall the dimensions of SQ are related to SS. This means that the better the SQ provided by the institutions of higher learning, the higher the SS. In this study, only three dimensions is relevant predictors for SQ namely responsiveness, assurance and empathy. This means that students perceive these three dimensions of SQ as more important qualities need to be offered by the universities. Looking at these three dimensions, students rated higher on intangible services rather than tangible services.

Among the five dimension measured, empathy is the strongest dimension correlated with customer satisfaction which means that the more the higher learning institution cares about the students in the institution, the more satisfied the student will be. The finding of the present study is consistent with the results of previous studies in terms of the direction of the relationship (Parasuraman et al., 1985, 1988; Sureshchandar et al., 2002; Azman et al., 2009; Ravichandran et al., 2010; Rahim et al., 2010)

\subsection{Theoretical and Practical Implications}

Theoretically, this study contributes to the body of knowledge when the service quality (SQ) measurement instrument was first time used to measure the service quality in public higher learning institutions in Malaysia. The high reliability value suggested that the SQ measurement instrument is suitable to be used in evaluating the quality of services provided by public universities. This study helps to expand the application of the SQ measurement 
instrument in education context particularly in eastern context.

Practically, finding of the study helps the management of the university to identify the weaknesses and strength in the present services offered to the students. The management of the university could take necessary action to improve and overcome these weaknesses to lead to better student satisfaction. Improvement on the quality of the equipment and facilities used by the student will help to increase the perceived tangibility of the equipment thus improve the reliability towards the services provided. On the other hand, they should also work hard to maintain other elements of service quality that students are currently satisfied with for example keep being responsive to student requirement and shows their concern towards student welfare. In addition to that, the SERVQUAL model and its implication on student satisfaction is least understood among Malaysian universities and students. This study would help in making the university among the pioneer adopter of SERVQUAL in the public higher learning institution in Malaysia as it has been proven that the dimension of service quality is suitable to measure the services administered by the university.

\subsection{Limitation and Future Research Directions}

This study has several limitations which provide opportunity for future research. First and foremost, this study is done only in one of the public higher learning institution. A study among students in private learning institution is needed as it would provide better understanding about the phenomena that claims that students in the private institution enjoyed a higher student satisfaction due to a better quality of service. The comparison among private and government universities would allow validation of the claim that private institution is better in providing quality services to the student.

Future researchers could also focuses on regional study which looks into the comparison of service quality of several public institutions across the region such as South East Asia. This study focuses only one of the public institutions in Malaysia. Therefore, by having a regional study, a comparison could be done to measure the differences in service quality and students satisfaction. A standard for benchmarking can be achieved and this could lead to a better quality for the service provided. Finally, this study looks only to the dimension of service quality and student satisfaction. Future research could probably look onto the relationship of service quality towards student's performance with student satisfaction as a mediating or moderating factor.

\subsection{Conclusion}

In conclusion, the research finding presented here contributes to the existing knowledge of service quality and customer satisfaction both theoretically and practically. The result shown in the study demonstrates the importance of all elements in service quality (SQ) in assuring the student's satisfaction (SS). The result from the research provides opportunities for university management to improve the weaknesses in the services offered to the student thus ensuring that the quality of services provided to the student is at the highest level and student get optimal satisfaction when studying in the particular higher learning institution. We hope that this research would stimulate more research attention on how SQ could help higher 
learning institution in delivering better satisfaction to students and at the same time, expand the research framework by examining and identifying various moderators and mediators that could enhance the existing relationship between SQ and SS.

\section{References}

Alexandris, K., Dimitriadis, N., \& Markate, D. (2002). Can perceptions of service quality predict behavioral intentions? An exploratory study in the hotel sector in Greece. Managing Service Quality, 12(4), 224 - 231. http://dx.doi.org/10.1108/09604520210434839

Azman, I., Muhammad Madi, A., \& Balakrishnan, P. (2009). Effect of service quality and perceive value on customer satisfaction. International Journal of Management Perspective, $3(1), 29-44$.

Babakus, E., \& Boller, G. W. (1992). An empirical assessment of the SERVQUAL scale. Journal of Business Research, 24(3), $253 \quad$ - 268. http://dx.doi.org/10.1016/0148-2963(92)90022-4

Belman, D. (1996). Major-league menus. Restaurant USA Magazine, September.

Berry, L. L. (1980). Service marketing is different. Business, 30((May - June)), 24 - 29.

Bigne, E., Moliner, M. A., \& Sancez, J. (2003). Perceived service quality and satisfaction in multi service organizations: the case of spanish public services. The Journal of Services Marketing, 17(4), 420 - 442. http://dx.doi.org/10.1108/08876040310482801

Bitner, M. J. (1990). Evaluating service encounters: the effects of physical surroundings and employee responses. Journal of Marketing, 54(4), 69 - 82. http://dx.doi.org/10.2307/1251871

Bitner, M. J., \& Hubbert, A. R. (1994). Encounter satisfaction versus overall satisfaction versus quality: the customer's voice. In R. T. Rust \& R. L. Oliver (Eds.), Service quality: new directions in theory and practice (pp. 72 - 94). Thousand Oaks, CA: Sage.

Bolton, R. N., \& Drew, J. H. (1991). A multistage model of customer's assessment of service quality and value. Journal of Consumer Research, 17(4), 365 - 384. http://dx.doi.org/10.1086/208564

Brown, T. J., Churchill Jr, G. A., \& Peter, J. P. (1993). Research note: improving the measurement of service quality. Journal of Retailing, 69(1), 127 - 139. http://dx.doi.org/10.1016/S0022-4359(05)80006-5

Cronin, J. J., \& Taylor, S. A. (1992). Measuring service quality: a re-examination and extension. Journal of Marketing, 56(3), 55 - 68. http://dx.doi.org/10.2307/

Dulen, J. (1998). Dazzling by design. Restaurants and Institutions, 108(20), 40 - 49.

Freeman, K. D., \& Dart, K. (1993). Measuring the perceived quality of professional business services. Journal of Professional Services Marketing, $9(1), \quad 27 \quad-\quad 47$. http://dx.doi.org/10.1300/J090v09n01_04

Gronroos, C. (1984). A service quality model and its markeitng implications. European 
Journal of Marketing, 18(4), 36 - 44. http://dx.doi.org/10.1108/EUM0000000004784

Grove, S. J., \& Fisk, R. P. (1983). The dramaturgy of services exchange: an analytical framework for service marketing. In L. L. Berry, G. Lynn Shostack \& G. D. Upah (Eds.), Emerging perspectives in service marketing. Chicago: American Marketing.

Grove, S. J., Fisk, R. P., \& Bitner, M. J. (1992). Dramatizing the service experience: a managerial approach. In Advances in services marketing management. Greenwich, CT: JAI Press.

Ham, L., \& Hayduk, S. (2003). Gaining competitive advantages in higher education: analyzing the gap between expectations and perceptions of service quality. International Journal of Value-Based Management, 16(3), $223 \quad$ - 242. http://dx.doi.org/10.1023/A:1025882025665

Harrison-Walker, L. J. (2000). Service quality in the hair salon industry. Journal of Business Discipline, 1, 37 - 52.

Hishamuddin, F. A. H., Azleen, I., Rahida, A. R., \& Mohd Zulkiflee, A. R. (2008). Service quality and student satisfaction: a case study at private higher education institutions. International Business Research, 1(3), 163 -175.

Hu, H. H., Jay, K., \& Thanika, D. J. (2009). Relationship and impacts of service quality, perceived value, customer satisfaction, and image: an empirical study. The Service Industries Journal, 29(2), 111 - 125. http://dx.doi.org/10.1080/02642060802292932

Ibanez, V. A., Hartmann, P., \& Calvo, P. Z. (2006). Antecedents of customer loyalty in residential energy markets: Service quality, satisfaction, trust and switching costs. Service Industries Journal, 26(6), 633 - 650. http://dx.doi.org/10.1080/02642060600850717

Joseph, M., \& Joseph, B. (1997). Service quality in education: a student perspective. Quality Assurance in Education, 5(1), 15 - 21. http://dx.doi.org/10.1108/09684889710156549

Kettinger, W. J., \& Lee, C. C. (1994). Perceived service quality and user satisfaction with the information services function. Decision Sciences, 25(5), $737 \quad$ - 766. http://dx.doi.org/10.1111/j.1540-5915.1994.tb01868.x

Kim, W. G., Lee, Y. K., \& Yoo, Y. J. (2006). Predictors of relationship quality and relationship outcomes in luxury restaurants. Journal of Hospitality \& Tourism Research, 30(2), 143 - 169. http://dx.doi.org/10.1177/1096348005285086

Klara, R. (2001). Please please me. Restaurant Business, 100(4), 22.

Lam, S. K. (1997). SERVQUAL: A tool for measuring patients' opinions of hospital service quality in Hong Kong. Total Quality Management, 8(4), 145 - 152. http://dx.doi.org/10.1080/0954412979587

Landrum, H., Prybutok, V. R., \& Zhang, X. (2007). A comparison of Magal's service quality instrument with SERPERF. Information and Management, 14(1), 104 - 113. http://dx.doi.org/10.1016/j.im.2006.11.002 
Lassar, V. M., Manolis, C., \& Winsor, R. D. (2000). How quality, value, image and satisfaction create loyalty at a Chinese telecom. Journal of Business Research, 60(3), 980 -986 .

Lovelock, C. H. (1981). Why marketing management needs to be different for services. In J. H. Donnelly \& W. R. George (Eds.), Marketing of services (pp. 5 - 9). Chicago: American Marketing.

Machleit, K. A., \& Mantel, S. P. (2001). Emotional response and shopping satisfaction: moderating effects of shopper attributions. Journal of Business Research, 54(2), 97 - 106. http://dx.doi.org/10.1016/S0148-2963(99)00093-4

McDougall, G. H. G., \& Levesque, T. (2000). Customer satisfaction with services: putting perceived value into the equation. Journal of Service Marketing, 14(5), 392 - 410. http://dx.doi.org/10.1108/08876040010340937

Monroe, K. B. (1990). Pricing: making profitable decisions. New York: McGraw-Hill.

Muhammed, E. M., Rizwan, Q. D., \& Ali, U. (2010). The impact of service quality on student's satisfaction in higher education institute of Punjab. Journal of Management Research, 2(2), 1 - 11.

Nek Kamal, Y. Y., Azman, I., Zubrina, R. J., \& Salomawati, I. (2010). Service quality dimensions, perceive value and customer satisfaction: abc relationship model testing. International Business Education Journal, 2(1), 1 - 18.

Nguyen, N., \& LeBlanc, G. (1998). The mediating role of corporate image on customers' retention decisions: an investigation in financial service. International Journal of Bank Marketing, 16(2), 52 - 65. http://dx.doi.org/10.1108/02652329810206707

Nunally, J. C. (1978). Psychometric theory ( $2^{\text {nd }}$ ed.). New York: McGraw Hill.

Oldfield, B., \& Baron, S. (2000). Student perceptions of service quality. Quality Assurance in Education, 8(2), 85 - 95. http://dx.doi.org/10.1108/09684880010325600

Parasuraman, A., Berry, L. L., \& Zeithaml, V. A. (1991). Refinement and reassessment of the SERVQUAL scale. Journal of Retailing, 67(4), 420 - 450.

Parasuraman, A., Zeithaml, V. A., \& Berry, L. L. (1985). A conceptual model of service quality and its implication for future research. Journal of Marketing, 49, 41 - 51. http://dx.doi.org/10.2307/1251430

Parasuraman, A., Zeithaml, V. A., \& Berry, L. L. (1988). SERVQUAL: a multipleitem scale for measuring consumer perceptions of service quality. Journal of Retailing, 64(1), 12 - 40.

Pariseau, S. E., \& McDaniel, J. R. (1997). Assessing service quality in schools of business. International Journal of Operations and Production Management, 23(2), 230 - 249.

Perkins, D. S. (1991). A consumer satisfaction, dissatisfaction and complaining behavior bibliography: 1982 - 1990. Journal of Satisfaction, Dissatisfaction and Complaining 
Behavior, 4, 194 - 228.

Philip, G., \& Hazlett, S. (1997). The measurement of service quality: a new P-C-P attributes model. International Journal of Quality and Reliability Management, 14(3), 260 - 280. http://dx.doi.org/10.1108/02656719710165482

Pitt, L. F., Watson, R. T., \& Kavan, C. B. (1995). Service quality: a measure of information systems effectiveness. MIS Quarterly, 19(2), 173 - 188. http://dx.doi.org/10.2307/249687

Price, L. L., Arnould, E. J., \& Tierney, P. (1995). Going to extremes: managing service encounters and assessing provider performance. Journal of Marketing, 59(2), 83 - 97. http://dx.doi.org/10.2307/1252075

Rahim, M., Osman, M., \& Ramayah, T. (2010). Service quality, customer satisfaction and loyalty: a test of mediation. International Business Research, 3(4), 72 - 80.

Ravichandran, K., Tamil Mani, B., Arun Kumar, S., \& Prabhakaran, S. (2010). Influence of service quality on customer satisfaction: application of SERVQUAL model. International Journal of Business and Management, 5(4), 117 - 124.

Rodie, A. R., \& Klein, S. S. (2000). Customer participation in services production and delivery. In T. A. Swartz \& D. Iacobucci (Eds.), Handbook of service marketing and management (pp. 111 - 126). Thousand Oaks, CA: Sage Publications, Inc.

Ruyter, K. (1997). Measuring service quality and service satisfaction: an empirical test of an integrative model. Journal of Economic Psychology, 18, $387 \quad$ - 406. http://dx.doi.org/10.1016/S0167-4870(97)00014-7

Ruyter, K., Wetzels, M., \& Bloemer, J. (1998). On the relationship between perceived service quality, service loyalty and switching costs. International Journal of Service Industry Management, 9(2), 155 - 168.

Shemwell, D. J., Yavas, U., \& Bilgin, Z. (1998). Customer-service provider relationships: an empirical test of a model of service quality, satisfaction and relationship oriented outcome. International Journal of Service Industry Management, 9, 155 - 168. http://dx.doi.org/10.1108/09564239810210505

Sivadas, E., \& Baker-Prewitt, J. (2000). An examination of the relationship between service quality, customer satisfaction, and store loyalty. International Journal of Retail and Distribution Management, 16(4), 363 - 379.

Spreng, R. A., \& Mackoy, R. D. (1996). An empirical examination of a model of perceived service quality and satisfaction. Journal of Retailing, 72(2), 201 - 214. http://dx.doi.org/10.1016/S0022-4359(96)90014-7

Sureshchandar, G. S., Chandrasekharan, R., \& Anantharaman, R. N. (2002). The relationship between service quality and customer satisfaction - a factor specific approach. Journal of Service Marketing, 16(4), 363 - 379. Doi: 10.1108/ 08876040210433248.

Teboul, J. (1991). Managing quality dynamics. Englewood Cliffs: Prentice Hall. 
Tribe, J., \& Snaith, T. (1998). From SERVQUAL to HOLSAT: holiday satisfaction in Varadero, Cuba. Tourism Management, $\quad 19(1), \quad 25 \quad$ - $\quad 34$. http://dx.doi.org/10.1016/S0261-5177(97)00094-0

Voss, G. B., Parasuraman, A., \& Dhruv, G. (1998). The roles of price, performance and expectations in determining satisfaction in service exchanges. Journal of Marketing, 63(October), 46 - 61. http://dx.doi.org/10.2307/1252286

Wilkie, W. L. (1990). Consumer Behavior ( $2^{\text {nd }}$ ed.). New York: Wiley.

Wisniewski, M. (2001). Using SERVQUAL to assess customer satisfaction with public sector service. Managing Service Quality, $11(6), \quad 380 \quad$ - $\quad 388$. http://dx.doi.org/10.1108/EUM0000000006279

Zeithaml, V. A. (1988). Consumer perception of price, quality and value: a means-end model and synthesis of evidence. Journal of marketing, 52(3), 2 - 22. http://dx.doi.org/10.2307/1251446

Zeithaml, V. A., \& Bitner, M. J. (2003). Services Marketing (3 ${ }^{\text {rd }}$ ed.). Boston, MA: McGraw-Hill Irwin.

\section{Copyright Disclaimer}

Copyright reserved by the author(s).

This article is an open-access article distributed under the terms and conditions of the Creative Commons Attribution license (http://creativecommons.org/licenses/by/3.0/). 